\title{
THEORETICAL AND EMPIRICAL LITERATURE OF THE RELATIONSHIP BETWEEN DEFENSE EXPENDITURES AND ECONOMIC GROWTH*
}

\section{SAVUNMA HARCAMALARI VE EKONOMIK BÜYÜME İLIŞKISINIIN TEORIKK VE AMPIRIKK LITERATÜRÜ}

\author{
Bayram AYDIN
}

Araştırma Makalesi / Geliş Tarihi: 11.01.2021

Kabul Tarihi: 30.06 .2021

\begin{abstract}
In the economics literature, it is considered that defense expenditure, which is characterized as public spending, may negatively affect growth either by crowding out effect of investments within the framework of the Neo-Classical Approach, or positively affect economic growth by increasing aggregate demand within the framework of the Keynesian Approach. Benoit examined the connection among defense expenditures and economic growth in developing countries in his study in 1973 and he revealed the existence of a positive relationship among the variables. This result has been described as the Benoit Hypothesis in the economics literature. Within the framework of the Benoit Hypothesis, the relationship between variables was studied in many academic articles. However, the findings obtained in the empirical literature made a difference, and a common conclusion could not be reached about the validity of the hypothesis. In this study, it is aimed to bring together the theoretical and empirical findings on the relationship between militariy expenditures and growth.
\end{abstract}

Keywords: Defense Expenditures, Economic Growth, Benoit Hypothesis, Literature Study

JEL Codes: H40, H50, H70

ÖZ

Kamu harcaması türlerinden olan savunma harcamaları, ekonomik büyümeyi Neo-Klasik Yaklaşım çerçevesinde yatırımların dışlanması yoluyla negatif etkilemektedir. Keynesyen Yaklaşıma göre ise, kamu harcamaları toplam talebin artırılması yoluyla ekonomik büyüme üzerinde pozitif etki yapmaktadır. Benoit, 1973 yılında yaptığı çalışmada gelişmekte olan ülkelerde ekonomik büyüme ve savunma harcamaları arasındaki ilişkiyi incelemiş ve değişkenler arasındaki pozitif bir ilişkinin varlığını ortaya koymuştur. Bu sonuç, iktisat yazınında Benoit Hipotezi olarak nitelendirilmiştir. Benoit Hipotezi çerçevesinde savunma harcamaları ve ekonomik büyüme arasındaki bağlantı çok sayıda akademik çalışmalarda incelenmiştir. Ancak, ampirik literatürde ulaşılan sonuçlar farklılık göstermiş ve hipotezin geçerliliği hakkında ortak bir neticeye varılamamıştır. Bu nedenle çalışmada, savunma harcaması ve iktisadi büyüme ilişkisine yönelik yapılan teorik ve ampirik bulguların bir araya getirilmesi hedeflenmiştir.

Anahtar Kelimeler: Savunma Harcamaları, Ekonomik Büyüme, Benoit Hipotezi, Literatür Çalışması

JEL Kodu: H40, H50, H70

\footnotetext{
${ }^{*}$ Bibliyografik Bilgi (APA): FESA Dergisi, 2021; 6(2), 208-215 / DOI: 10.29106/fesa.858707

† Araştırma Görevlisi, Yozgat Bozok Üniversitesi, İktisadi ve İdari Bilimler Fakültesi, İktisat Bölümü, bayram.aydin@yobu.edu.tr, Yozgat, Türkiye, ORCID ID: 0000-0003-4238-7779.
} 


\section{Introduction}

Defense expenditure is described as a public good in the economic literature. Public goods; It has the characteristic of not being excluded and its use by one person does not reduce the use of other people. Defense expenditures incorporate these characteristics. Individuals cannot be excluded from the use of public goods. The defense system protects all country citizens equally. Moreover, the defense service offered to a citizen does not hinder the protection of other individuals and does not reduce the levels of protection offered to other individuals.

Public goods are goods that benefit the general public and therefore must be produced. However, it is necessary to determine at what rate it will be produced, taking into account the opportunity cost. Otherwise, it causes the Free Rider Problem, as stated in the economics literature. Free rider problem; It is a situation where people benefit from property and avoid paying for it. This is a market failure and this problem is increasing due to externality.

The need for defense is one of the most important needs of humanity. In Maslow's Hierarchy of Needs Theory, defense requirements are defined as body, Family, Work, Health, and property security. The defense service is one of the most vital tasks of the public authority. But the defense service has an economic dimension and it is called defense spending (Tuncay, 2017; 24).

Tablo 1. Defense Spending of Selected Countries

\begin{tabular}{|c|c|c|c|c|c|c|c|c|}
\hline Değişken & Ülke & 2013 & 2014 & 2015 & 2016 & 2017 & 2018 & 2019 \\
\hline \multirow{7}{*}{$\begin{array}{c}\text { Military } \\
\text { Expenditure as } \\
\text { Percentage of } \\
\text { Government } \\
\text { Spending }\end{array}$} & USA & $11,3 \%$ & $10,4 \%$ & $9,9 \%$ & $9,6 \%$ & $9,4 \%$ & $9,4 \%$ & $9,4 \%$ \\
\hline & Germany & $2,7 \%$ & $2,6 \%$ & $2,5 \%$ & $2,6 \%$ & $2,6 \%$ & $2,6 \%$ & $2,8 \%$ \\
\hline & Russia & $11,1 \%$ & $11,8 \%$ & $13,8 \%$ & $14,8 \%$ & $12,1 \%$ & $11,4 \%$ & $11,4 \%$ \\
\hline & Turkey & $5,7 \%$ & $5,7 \%$ & $5,5 \%$ & $5,9 \%$ & $6,1 \%$ & $7,4 \%$ & $7,8 \%$ \\
\hline & Greece & $4,6 \%$ & $4,6 \%$ & $4,8 \%$ & $5,2 \%$ & $5,3 \%$ & $5,7 \%$ & $5,4 \%$ \\
\hline & UK & $5,0 \%$ & $4,8 \%$ & $4,7 \%$ & $4,7 \%$ & $4,6 \%$ & $4,6 \%$ & $4,5 \%$ \\
\hline & Brazil & $3,6 \%$ & $3,5 \%$ & $3,5 \%$ & $3,4 \%$ & $3,7 \%$ & $3,9 \%$ & $3,9 \%$ \\
\hline \multirow{7}{*}{$\begin{array}{c}\text { Military } \\
\text { Expenditure, } \\
\text { (In Constant } \\
2018 \text { US\$ M.) }\end{array}$} & USA & 732148 & 687112 & 671509 & 669448 & 662550 & 682491 & 718689 \\
\hline & Germany & 41980 & 41032 & 40888 & 43784 & 45340 & 46512 & 51190 \\
\hline & Russia & 63800 & 68378 & 73694 & 79007 & 63652 & 61388 & 64144 \\
\hline & Turkey & 11868 & 11955 & 12302 & 14423 & 15480 & 19649 & 20796 \\
\hline & Greece & 4920 & 4880 & 5175 & 5390 & 5386 & 5757 & 5732 \\
\hline & UK & 52355 & 50996 & 49838 & 49912 & 49412 & 49892 & 49916 \\
\hline & Brazil & 26229 & 26754 & 26134 & 24807 & 26424 & 28177 & 28030 \\
\hline
\end{tabular}

Source: Stockholm International Peace Research Institute

\section{https://www.sipri.org/databases/milex}

Military spending has an significant place in public spending of countries. In the selected countries shown in Table 1, Military expenditure as percentage of government spending tends to increase in developing countries such as Turkey, Brazil and Greece, while in these countries it tends to decrease in developed countries such as UK, Germany and USA. The situation that draws attention to the Table 1 is that Turkey increased its military spending almost 2 times, from 11868 US\$m in 2013 to 20796 US\$m in 2019. It is undeniable that such a large increase in defence spending have significant effect on the country economies. The military expenditure variable, which experienced great increases, attracted attention in the economics literature and caused long-term studies. Economists have studied the long-term effects of military spending on macroeconomic indicators.

The causal connection among defence expenditures and growth become also one of the most studied topics in the literature. There are 4 cases of causality that can be reached for countries. These; there is no causality among variables, uni-directional causality from defence expenditures to growth, uni-directional relationship from growth to defence expenditures, and bi-directional causality between variables. These findings indicate the following: (i) that countries with no relationship between variables can set defense policy goals independent of economic growth policy goals; (ii) where uni-directional relationship from growth to defence expenditures, defense decisions in the country are not taken in a way that encourages growth; (iii) where uni-directional causality from military expenditures to growth, military spendings are used effectively for growth goals and (iv) in the case of dual causality, it means that both growth and defense policy goals are achieved together (Saba and Ngepah, 2019; 3586). 


\section{Theoretical Literature of the Relationship Between Economic Growth and Defense Expenditures}

The literature on military expenditures and economic growth have two mainly different theoretical views such as The Military Keynesianism Approach and Neo-Classical Approach.

The Military Keynesianism Approach is based on the Keynesian Expenditure Theory as its starting point, and states that the increases in military spending will significantly increase investments and the size of the economy through the multiplier effect. The Military Keynesianism Approach explains the impacts of military spending on economic growth with "supply-side" factors, basing it on positive externalities. Under this approach, more defense expenditures can have important multiplier effect. The demand created by military spending increases capacity utilization and increases the output level. The result is an increase in the rate of capital earnings, investments and economic growth (Looney, 1994: 46-47). According to Military Keynesianism, defense expenditures have positive externalities. Factor productivity can increase thanks to these externalities. These externalities include all of the non-numerical factors such as modernization, stability and discipline, as well as training of military personnel, infrastructure building and technical methods that multiply through military research and development. New technologies, especially R\&D activities, will spread to the whole society. As a matter of fact, almost all of the inventions in the fields of transportation and electronics were realized to military reasons for the first time (Giray, 2004: 189).

The Neo-Classical approach has judgments contrary to the Keynesian Military view. It states that, since defense expenditures arise due to a vital need, regardless of whether they are economically and socially productive, the state will not be able to transfer resources to alternative areas, and as a natural consequence of this, the economic growth performance will remain well below the potential (Alptekin, 2012: 205). Neo-classical Theoretical Approach explains the impact of defense expenditures on growth with "demand-side" factors based on negative externalities. According to this approach, defense spending diverts scarce resources directly from productive investments and human capital accumulation. Thus, defense expenditures may cause a high opportunity cost by shifting the resources to be used in development projects with high growth rates to other areas. This reduces not only non-defense public spending but also associated private spending. Consequently, defense spending may cause the exclusion effect of investments (Dunne and Nikolaidou, 2005: 5; Giray, 2004: 190; Looney, 1994: 36).

While Military Keynesianism view, which thinks that defense spending on the axis of the Keynesian Expenditure Theory will affect the economic growth performance positively, supports the Benoit Hypothesis, the Neo-Classical approach suggests that the Benoit Hypothesis is invalid with the view that defense spending may delay growth by crowding out effect of investments.

Benoit (1973) revealed positive connection among military expenditures and economic growth in developing countries in his 1973 study. In his other study, Benoit (1978) argued that, countries with heavy defense burden were mostly showed the fastest economic growth rates and countries with the lowest defense burden showed the lowest economic growth rates. Benoit not only used growth, which is an increase in defense spending, but also used a different Growth Index, mainly including civilian growth and the rate of increase in non-defense production in the study. Benoit (1978) initially discovered the strong positive correlation among high military spending and rapid growth rates in quartile data analysis, then supplemented with Spearman Rank Correlation Analysis and verified by regression analysis. This area where Benoit works has been described as the Benoit Hypothesis in the economics literature and this hypothesis is known as the existence of positive relationship among growth and defence expenditures in the literature.

Since Benoit's (1973) periodic study, the economic effect of military expenditures in developing countries have become subject of wide empirical research. Theoretically, nevertheless, there are no exact prediction of the correlation and direction of causality among military expenditures and growth. Military expenditures may delay growth by the crowding out effect of investments. In contrast to this situation, military expenditures can also encourage growth by the Keynesian aggregate demand effect. The rising of demand created through higher defence expenditures can lead to more use of the higher employment, capital stock, profits and consequently higher investments through the creation of the multiplier effect (Dakurah, Davies and Sampath, 2001: 652). 


\section{Empirical Literature on the Relationship Between Economic Growth and Defense Expenditures}

The literature among economic growth and military spending gained momentum after Benoit (1978). This field has been described as the Benoit Hypothesis and this hypothesis is known as the existence of a positive relationship among military expenditures and growth. However, result of studies that failed to reach any consensus, and this has led to a large number of empirical studies. Benoit (1978) conducted his study on forty-four developing countries, including Turkey, with data from the period 1950-1965. Benoit (1978) concluded that military spending positively impacted economic growth. Following this milestone study, researches have increased for many regions and countries in this field.

Joerding (1986) used Granger causality analysis by employing data from the period 1962-1977 for 57 developing countries, including Turkey. In the study, a one-way causality relationship has been reached from growth to defense spending. This result implies that defence expenditures are not an exogenous variable and that Benoit Hypothesis is flawed. Also, Alexander (1990), in his study on the 9 developing country economies for the period 1974-1985, claims that there isn't statistically significant relationship between variables, that previous studies in this area are flawed.

Chowdhury (1991) investigated the causality on 55 developing countries. Granger causality analysis is applied in order to test existence of causality connection. The results show that the interaction among variables can not be generalized for all countries. In addition to the differences in the socioeconomic structure and management styles of the countries, the different sample sets applied in the analyzes cause the results obtained to differ between countries. In addition, the results showed the conclusion that there isn't causal connection among the variables in most countries.

Mintz and Stevenson (1995) using data from 1950 to 1985 on 103 countries within the framework of the Feder-Ram type 3-sector growth model, found that in most countries, expenditures other than defense spending had significant and positive effect on growth, however that the effect of military expenditure is insignificant. The results has shown that defence expenditures have significant positive impact on economic growth in $10 \%$ of the samples.

Dunne and Vougas (1999) applied the Granger Causality test based on VAR methodology in their work on South Africa. In the study, it has been seen that the military burden has a significant negative impact on growth. Batchelor, Dunne and Saal (2000) applied the ARDL analysis in their study on the South African economy and found that defence spending did not has significant impact on growth in total, but had significant negative effects for the manufacturing sector.

Dritsakis (2004) applied Johansen cointegration tests with the VECM model in his study, in which he investigated the connection among variables to Turkey and Greece. While the study proves that the two variables do not have a long-term cointegration relationship, the Granger causality analysis results show that there is a unilateral causality connection from growth to military spending to both countries. In addition, another important result reached in the study is to reach a bidirectional causality relationship that shows the feedback situation between the defense expenditures of the two countries. This situation indicates that the two neighboring countries mutually increase their defense spending.

Kollias, Manolas and Paleologou (2004) investigated the connection among economic growth and military expenditures for 15 European Union member countries. Although reported results do not show integrity between the 15 countries, the apparent prevalence of causality in terms of economic growth towards defence spending and the absence of reverse causal order has been determined in the study. Dunne and Nikolaidou (2005) contributed to the literature by taking into account Greece, Portugal and Spain, which are the three poorest environmental economies of the European Union. In the study, Benoit Hypothesis was investigated using Granger causality methods within a unified Vector Autoregressive (VAR) framework. Results from these different methods are inconsistent and demonstrate inference problems even among relatively homogeneous economies. There was no evidence that the joint VAR results for Greece showed the positive effect of military burden on growth as opposed to negative impact to Spain, whereas for Portugal there was no causal linkage.

Karagianni and Pempetzoglu (2009) are used linear and nonlinear Granger causality methods to test Benoit Hypothesis in Turkey for the period 1949-2004. This is concluded that there is a linear causality relationship from growth to defence expenditures and a non-linear causality relationship from to defence expenditures to growth. Y1lanc1 and Özcan (2010) analyzed the existence of the connection among GDP and defence expenditures for Turkish Economy between 1950-2006 with the Toda-Yamamoto causality and Gregory-Hansen cointegration tests. The results obtained in the analysis showed that there was no long-run cointegration connection. The causality analysis revealed unidirectional causality link from growth to defense expenditures. Khalid and 
Habimana (2019) used the wavelet theory to explain Benoit Hypothesis in the Turkish Economy. The results reject views that defence expenditures can stimulate growth. It shows that this situation does not valid in Turkey. Kanca and Yamak (2020) examined the validity of the Benoit Hypothesis with data for the Turkish economy between 1980-2017. ARDL co-integration and Toda-Yamamoto causality tests are applied and a long-run negative connection among military expenditures and growth was detected in the study. Furthermore, Toda-Yamamoto causality results which was determined that there was bidirectional causality. Generally, studies examining the relationship between defense spending and economic growth in Turkey showed different findings.

Wijeweera and Webb (2011) applied the panel co-integration analysis to examine the Benoit Hypothesis for 5 South Asian countries during 1988-2007. It found that a 1\% increase in defence expenditures increased real GDP by only $0.04 \%$, demonstrating that the substantial amount of public spending for military purposes in these countries had a negligible effect on growth. Shahbaz and Shabbir (2012) reexamined the causality among defence expenditures and growth for Pakistan applying ARDL model. The long-term relationship among variables were determined in the study. And also, negative oneway causality connection from defence expenditures to growth were determined in the study.

Feridun, Sawhney and Shahbaz (2011) aimed to examine causality connection among defence expenditures and growth in Northern Cyprus using the ARDL analysis for the period 1977-2007. The results show that these variables have longterm equilibrium relationship and that there is a strong, positive one-way causal relationship that extends from military expenditures to growth.

Yurtançıkmaz, Aali and Emsen (2012) studied the impacts of sanctions, embargoes and defence expenditures on economic growth for the Iranian economy with the ARDL bound test approach. In the study, it was concluded that external openness and military spending in the long term have positive impact on growth, that military expenditures in the short term had a statistically significant and positive effect on growth, however that external openness did not have a significant impact on growth. Farzanegan (2014) examined the connection among military expenditures and growth in contradictory environment, underlining that the military budget of the Iranian government has been above the world average in the last decade. The Granger causality results in the study showed that there is unidirectional causal relationship from defence expenditures to growth.

Alptekin (2012) examined the Benoit Hypothesis for 24 OECD countries with panel data analysis by employing data from 1991-2008. In the study, using Pedroni, Kao and Johansen Fisher panel cointegration plants, it was concluded that military spendings have negative impact on growth.

Duyar and Koçoğlu (2014) examined Benoit Hypothesis with the help of panel GLS and external growth model methods by employing the data between 1990-2012 for six Sub-Saharan African countries. The results have shown that defence spending has negligible positive impact on growth to macro scale.

Pan, Chang, and Wolde-Rufael (2015) reviewed Benoit Hypothesis for 10 Middle Eastern countries through a panel causality test that takes into account cross-sectional dependence and heterogeneity between countries in the period 1988-2010. In the study, the link of unilateral causality from defence expenditures to growth was only observed on Turkey. Also, link of unilateral causality from growth to defence expenditures was observed for Kuwait, Egypt, Lebanon and Syria; bi-directional causality was only observed for Israel and no causality relationship has been observed for Jordan, Oman and Saudi Arabia. Kesgingöz and Olcay (2016) also examined the direction of relations between defence expenditures and growth for Turkey and selected Middle Eastern countries using panel data analysis using data from 1991-2014. In the Study, 2 different models were established and it was concluded that there is a negative connection among defence spendings and growth. The empirical results obtained in the study support the Neo-classical view that military expenditures will reduce economic growth.

Destek and Okumuş (2016) investigated the causality connection among defence spending, real capital stock and growth in BRICS and MIST countries. In the study, the Bootstrap Panel Granger Analysis was used for the period between 1990 and 2013. The results show cross-sectional dependence and country-specific heterogeneity between the BRICS and MIST countries. In addition, a positive and one-sided causal relationship has been achieved in the direction of economic growth in defense spending in China. In contrast, in Turkey, a negative and one-sided causal relationship has been reached from defence spending to growth. Also in the study, feedback hypothesis for Russia and the neutrality hypothesis to Indonesia, India, Brazil, South Korea, South Africa and Mexico are supported by data.

Sua, Xub, Changc, Lobontd, and Liue (2018) investigated the causality link among variables for China using the Bootstrap Granger Analysis. Findings show that there is positive bidirectional causality. This situation shows that more defense spending in China will increase economic growth and vice versa. Raju and Ahmed (2019) conducted an empirical analysis of the impact of defence spending on growth using cointegration analysis and Granger causality tests on India, Pakistan and China. In the study, in which the short and long-term relationship 
between GDP growth and military expenditures was analyzed, a positive long-term cointegration relationship, short-term relationship and a unilateral longterm causality from military expenditures to GDP was found to all cases. Abdel-Khalek, Mazloum and El Zeiny (2019) aimed to study this complex connection for India. Hendry General to Specific model was used to determine connection among variables in period 1980-2016. Obtained results showed that there isn't causality relationship between variables in India in the indicated period.

Saba and Ngepah (2019) investigated the causality relationship among defence spending and growth with a balanced panel of 35 African countries between 1990-2015. In the study, there is no causality relationship for variables in 7 countries; empirical tests have revealed that there is a one-sided causality relationship from military expenditures to growth in 2 countries and from growth to military expenditures in 14 countries, and a bidirectional causality in 12 countries.

\section{Conclusion}

In the economics literature, it is considered that defense expenditure, which is characterized as public spending, may negatively affect economic growth either through crowding out effect of investments within the framework of the Neo-Classical Approach, or positively affect economic growth by increasing aggregate demand within the framework of the Keynesian Approach. This situation differs according to countries and regions. This field of study has been described as the Benoit Hypothesis in the economics literature and the Benoit Hypothesis is known as the existence of a positive relationship between military spending and economic growth. Benoit argued that countries with heavy defense burden often had the fastest economic growth rates, and countries with the lowest defense burden showed the lowest economic growth rates. Determining whether defense spending is an auxiliary element for economic growth and determining the extent to which defense spending affects economic growth provide important implications for policy makers of countries.

In the economics literature, it is expected that the Benoit Hypothesis, which advocates the positive relationship between defense spending and economic growth, in analyzes for developing countries. The results obtained from empirical studies generally support the economics literature and show that defense spending in developing countries is an auxiliary factor for economic growth. The situation where defense spending causes economic growth and this relationship is not the opposite is important because military spending is an effective tool for economic growth targets in developing countries and it shows that defense decisions are capable of promoting economic growth. The findings obtained mostly in the empirical literature show that defense expenditures can positively affect economic growth through the increase of aggregate demand within the framework of Keynesian Approach. While the results generally support the Keynesian view in the empirical literature, they reject the Neo-classical approach (the view that military spending may adversely affect economic growth through the crowding out of investments). The obtained results show that the defense industry is a fertile area for investments in developing countries. The return of the increase in military spending to the economies of developing countries is positive. For this reason, it is recommended that investments made in this area are made more efficient and therefore contribute to economic growth. Furthermore, in addition to the positive impact of military spending on economies, defense investments will contribute to the stability of economic activities against the economic and political problems.

\section{References}

ABDEL-KHALEK, G., MAZLOUM, M. G. and EL ZEINY, M. R. M. (2019). Military expenditure and economic growth: the case of India. Review of Economics and Political Science, 1-20.

ALEXANDER, W. R. J. (1990). The Impact of Defence Spending on Economic Growth: A Multi-Sectoral Approach to Defence Spending and Economic Growth with Evidence from Developed Economies. Defence Economics, 2(1), 39-55.

ALPTEKİN, V. (2012). Benoit Hipotezi: Seçilmiş OECD Ülkeleri Ölçeğinde Panel Veriler Yardımıyla Analizi. Celal Bayar Üniversitesi Sosyal Bilimler Dergisi, 10(2), 204-215.

BATCHELOR, P., DUNNE, J. P., and SAAL D. S. (2000) Military spending and economic growth in South Africa. Defence and Peace Economics, 11(4), 553-571.

BENOIT, E. (1973). Defense spending and economic growth in developing countries. Lexington: Lexington Books.

BENOIT, E. (1978). Growth and Defense Expenditure. Economic Development and Cultural Change, 26(2), 271280. 
CHOWDHURY, A. (1991), A Causal Analysis of Defense Spending and Economic Growt. The Journal of Conflict Resolution, 35(1), 80-97.

DAKURAH, A. H., DAVIES, S. P. and SAMPATH, R. K. (2001). Defense spending and economic growth in developing countries A causality analysis. Journal of Policy Modeling, 23, 651-658.

DESTEK, M. A. and OKUMUŞ, I. (2016). Military Expenditure and Economic Growth in BRICS and MIST Countries: Evidence From Bootstrap Panel Granger Causality Analysis. South-Eastern Europe Journal of Economics, 2, 175-186.

DRİTSAKIS, N. (2004). Defense Spending and Economic Growth: An Empirical Investigation For Greece and Turkey. Journal of Policy Modelling, 26(2), 249-264.

DUNNE, J. P. and NIKOLAIDOU, E. (2005). Military Spending and Economic Growth in Greece, Portugal and Spain. Web: https://ideas.repec.org/p/uwe/wpaper/0510.html

DUNNE, P. and VOUGAS, D. (1999). Military Spending and Economic Growth in South Africa: A Causal Analysis. The Journal of Conflict Resolution, 43(4), 525-536.

DUYAR, M. and KOÇOĞLU, M. (2014). Askeri Harcamaların Ekonomik Büyüme Üzerine Etkisi; Sahra Altı Afrika Örneği. Uluslararası Sosyal Araştırmalar Dergisi, 7(33), 703-704.

FARZANEGAN, M. R. (2014) Military Spending and Economic Growth: The Case of Iran. Defence and Peace Economics, 25(3), 247-269.

FERIDUN, M., SAWHNEY, B. and SHAHBAZ, M. (2011). The Impact of Military Spending on Economic Growth: The Case of North Cyprus. Defence and Peace Economics, 22(5), 555-562.

GİRAY, F. (2004). Savunma Harcamaları ve Ekonomik Büyüme, Cumhuriyet Üniversitesi İktisadi ve İdari Bilimler Dergisi, 5(1), 181-199.

JOERDING, W. (1986). Economic Growth and Defense Spending Granger Causality. Journal of Development Economics, 21(1), 35-40.

KANCA, O. C. and YAMAK, R. (2020). Türkiye Ekonomisi Açısından Benoit Hipotezinin Testi. Gaziantep University Journal of Social Sciences, 19(3), 823-839.

KARAGIANNI, S. and PEMPETZOGLU, M. (2009). Defense Spending and Economic Growth in Turkey: A Linear and Non-Linear Granger Causality Approach. Defence and Peace Economics, 20(2), 139-148.

KESGINGOZ, H. and OLCAY, T. (2016). Türkiye ve Seçilmiş Ortadoğu Ülkeleri için Benoit Hipotezinin Sınanması: Panel Veri Analizi. Çankırı Karatekin Üniversitesi İktisadi ve İdari Bilimler Fakültesi Dergisi, 6(1), 585-607.

KHALID, U. and HABIMANA, O. (2019). Military Spending and Economic Growth in Turkey: A Wavelet Approach. Defence and Peace Economics, doi: 10.1080/10242694.2019.1664865

KOLlias, C., GEORGE, M. and PALEOLOGOU, S-M. (2004). Defence Expenditure and Economic Growth in The European Union A Causality Analysis. Journal of Policy Modeling, 26(5), 553-569.

LOONEY, R. E. (1994). The Economics of Third World Defense Expenditures, London: Ja1 Press, Inc.

MINTZ, A. and STEVENSON, R. T. (1995). Defense Expenditures, Economic Growth, and the Peace Dividend: A Longitudinal Analysis of 103 Countries. The Journal of Conflict Resolution, 39(2), 283-305.

PAN, C., CHANG, T. and WOLDE-RUFAEL, Y. (2015). Military Spending and Economic Growth In The Middle East Countries: Bootstrap Panel Causality Test. Defence and Peace Economics, 26(4), 443-456.

RAJU, M. H. and AHMED, Z. (2019). Effect of military expenditure on economic growth: evidences from India Pakistan and China using cointegration and causality analysis. Asian Journal of German and European Studies, 4(3), 1-8.

SHAHBAZ M. and SHABBIR M. S. (2012) Military Spending and Economic Growth in Pakistan: New Evidence from Rolling Window Approach. Economic Research-Ekonomska Istraživanja, 25(1), 119-131.

SABA, C. S. and NGEPAH, N. (2019). Military expenditure and economic growth: evidence from a heterogeneous panel of African countries. Economic Research, 32(1), 3586-3606. 
SUA, C., XUB, Y., CHANGC, H. L., LOBONTD, O. R. and LIUE, Z. (2018). Dynamic Causalities between Defense Expenditure and Economic Growth in China: Evidence from Rolling Granger Causality Test. Defence And Peace Economics, 1-18.

TUNCAY, Ö. (2017). Finansal Serbestleşme Sonrası Dönem Savunma Harcamalarının Ekonomik Analizi. International Journal of Economic Studies, 3(1), 23-37.

WIJEWEERA, A. and WEBB, M. J. (2011). Military Spending and Economic Growth in South Asia: A Panel Data Analysis, Defence and Peace Economics, 22(5), 545-554.

YILANCI, V. and ÖZCAN, B. (2010). Yapısal Kırılmalar Altında Türkiye İçin Savunma Harcamaları İle GSMH Arasındaki İlişkinin Analizi. C. ̈̈. İktisadi ve İdari Bilimler Dergisi, 11(1), 21-33.

YURTTANÇIKMAZ, Z. Ç., AALI, A. and EMSEN, Ö. S. (2012). Askeri Harcamalar ve Ambargonun Ekonomik Büyümeye Etkileri: İran Üzerine Bir Uygulama. Atatürk Üniversitesi İktisadi ve İdari Bilimler Dergisi, 26(2), 171-190. 